\title{
Increased cell loss in the human jejunum induced by laxatives (ricinoleic acid, dioctyl sodium sulphosuccinate, magnesium sulphate, bile salts)
}

\author{
J F BRETAGNE, N VIDON, CH L'HIRONDEL, AND J J BERNIER \\ With the technical assistance of M Bovet, M Maurel, M Rongier, and J Rouchette
}

From the Unité de Recherche sur la Physiopathologie de la Digestion, INSERM U54, Hôpital Saint-Lazare, Paris, France

SUmmary Two conjugated bile salts $(10 \mathrm{mmol} / 1$ sodium glycocholate, $10 \mathrm{mmol} / \mathrm{l}$ sodium taurodeoxycholate) and three laxatives $(30 \mathrm{mmol} / \mathrm{l}$ magnesium sulphate, $10 \mathrm{mmol} / \mathrm{l}$ ricinoleic acid, $2 \mathrm{mmol} / \mathrm{l}$ dioctyl sodium sulphosuccinate) were tested on seven subjects with no intestinal lesions in 14 experiments by intestinal perfusion of the jejunum. A $25 \mathrm{~cm}$ segment was studied. Each solution was perfused at the rate of $10 \mathrm{ml} / \mathrm{min}$. Water and electrolyte fluxes, losses of deoxyribonucleic acid (DNA), and intestinal cell enzyme activity were measured in the fluids collected. All the laxatives and bile salts tested (except sodium glycocholate) induced water and electrolyte secretion, a rise in intraluminal DNA loss, and enzyme activity. It was possible to establish a significant correlation $(\mathrm{P}<0.001)$ between the amounts of water fluxes and DNA loss under the effect of dioctyl sodium sulphosuccinate and ricinoleic acid.

The effect of the bile acids, ${ }^{1-4}$ dioctyl sodium sulphosuccinate (DOSS), ${ }^{56}$ ricinoleic acid, ${ }^{7}$ and magnesium sulphate $\left(\mathrm{MgSO}_{4}\right)^{8} 9$ on intestinal water and electrolyte movements no longer requires demonstration either in the human subject or in animals, as regards both the small intestine and the colon. The mechanism of action is probably not unequivocal, combining alteration of intestinal motility, ${ }^{10}$ action on active transport (membrane ATPase), ${ }^{11}$ hormone liberation, ${ }^{8}$ an increase in intracellular cyclic AMP ${ }^{12} 13$ and morphological epithelial changes with alteration of intestinal permeability. Ultrastructural changes in the mucosa of the small intestine under the influence of the bile acids, ricinoleic acid, and DOSS have been demonstrated either directly by microscopic technique ${ }^{1415}$ (the changes involve the villus tips, producing disruption of the mucosal barrier) or indirectly by an increase of cell markers (deoxyribonucleic acid, phospholipids, sucrase) in the perfusion fluids. ${ }^{15}$ Increased intestinal permeability has been demonstrated by measurement of intestinal clearance of inulin, dextran, albumin ${ }^{15}$ and chromium 51 EDTA. ${ }^{16}$ There is a direct relationship between intestinal

Received for publication 29 October 1980 secretion and permeability according to Cline, ${ }^{14}$ but not according to Binder. ${ }^{2}$ The purpose of this study was therefore to determine the part played by the bile acids and three laxatives selected from the various groups of the international classification ${ }^{17}$ (ricinoleic acid, DOSS, $\mathrm{MgSO}_{4}$ ) in cell desquamation, quantifying the phenomenon by measuring the DNA and intestinal cell enzymes in the perfusion fluids, and to attempt to establish a correlation with water and electrolyte secretion.

\section{Methods}

INTESTINAL PERFUSION

The bile acids and laxatives were tested on seven constipated patients free from intestinal disease, using the technique of intestinal perfusion described by Modigliani and Bernier. ${ }^{18}$ The perfusion point (A) was at the angle of Treitz below an occlusive balloon. A $25 \mathrm{~cm}$ segment was studied. The fluid was perfused at $37^{\circ} \mathrm{C}$ at a rate of $10 \mathrm{ml} / \mathrm{min}$. After collection (at point $\mathrm{B}$ ) all the samples were homogenised in a $30 \mathrm{ml}$ Potter Elvehjem tissue homogeniser (Vitro Laboratories).

The laxative was perfused for two hours, made up of a 30 minute equilibration period and three $\mathbf{3 0}$ 
minute collections. Perfusion of the laxative was preceded by perfusion of a blank solution (of the same composition minus the laxative) for 90 minutes, made up of a 60 minute equilibration period and one 30 minute collection. It was also followed by perfusion of the same blank solution for 60 minutes, made up of two 30 minute collections.

\section{SOLUTIONS TESTED}

All the solutions contained $130 \mathrm{mEq} / \mathrm{l}$ sodium, $5 \mathrm{mEq} / \mathrm{l}$ potassium, $10 \mathrm{~g} / \mathrm{l}$ polyethylene glycol (PEG) 4000 used as a marker of water movements. Isotonicity was obtained where necessary by the addition of mannitol. The $\mathrm{pH}$ of the solution containing the laxative and the blank one was the same.

The ricinoleic acid (Sigma Laboratories) was perfused in a concentration of $10 \mathrm{mmol} / 1$ in three cases, DOSS in a concentration of $2 \mathrm{mmol} / \mathrm{l}$ in three cases, $\mathrm{MgSO}_{4}$ (UCB Laboratories) in a concentration of $30 \mathrm{mmol} / 1$ in four cases, sodium taurodeoxycocholate (TDC) in a concentration of $10 \mathrm{mmol} / \mathrm{l}$ in three cases, sodium glycocholate in a concentration of $10 \mathrm{mmol} / 1$ in three cases (Calbiochem Laboratories).

\section{BIOCHEMICAL DETERMINATIONS}

PEG was measured by Hyden's turbidimetric method. ${ }^{19}$ Sodium and potassium were measured by flame photometry, using a Technicon autoanalyser. Mannitol determination was carried out by the method of Corcoran and Page..$^{20}$ DNA was measured by the fluorometric method of Le Pecq and Paoletti, ${ }^{21}$ using ribonuclease (III A Sigma) to hydrolyse ribonucleic acid; the reference standard was calf thymus DNA (Koch-Light Laboratories). All determinations were made in duplicate, with appropriate blanks and a standard for each set of determinations.

Enzyme activity, alkaline phosphatase, $\alpha$-glucosidase, and $\mathrm{N}$ acetyl $\beta$-glucosaminidase were determined by the method described by Peters, Muller, and De Duve, ${ }^{22}$ leucyl $\beta$-naphthylamidase by the method described by Peters. ${ }^{23}$ All determinations were made in duplicate. Enzyme activity was expressed in $\mathrm{mU}$, one $\mathrm{mU}$ corresponding to hydrolysis of one nanomole of substrate per minute at $37^{\circ}$.
Sodium TDC was determined by the enzymatic method of Iwata. ${ }^{24}$

\section{CALCULATIONS}

Net transparietal water and electrolyte movements have been expressed respectively in $\mathrm{ml} / \mathrm{mn} / 25 \mathrm{~cm}$ and $\mu \mathrm{mol} / \mathrm{mn} / 25 \mathrm{~cm}$ of jejunum. The plus sign means secretion, the minus sign absorption. ${ }^{25}$

Outputs of DNA and enzyme activity at the collection point have been calculated and expressed in $\mu \mathrm{g} / \mathrm{mn} / 25 \mathrm{~cm}$ and $\mathrm{mU} / \mathrm{mn} / 25 \mathrm{~cm}$ respectively.

$$
\text { For each sample the ratio } \frac{\text { mann } A / \text { mann } B}{\text { PEG A/PEG B }}
$$

was calculated, where mann $A$ and mann $B$ are the concentrations of mannitol at A-perfusion pointand $B-$ collection point-respectively. This ratio is equal to 1 if PEG and mannitol are equally inabsorbable. If this ratio is less than 1 , it means that a certain amount of mannitol has been absorbed compared with PEG.

For the statistical study the matched series comparison test and the correlation coefficient were used.

\section{Results}

\section{WATER AND ELECTROLYTE FLUXES}

During the basal period a net absorption of water is observed. Under the effect of all the laxatives and of sodium taurodeoxycholate (Table 1) there is a net secretion of water; sodium glycocholate induces only a non-statistically significant reduction in absorption.

The kinetics of water secretion are shown in Fig. 1: with $\mathrm{MgSO}_{4}$ and TDC the secretion is constant during the two hours of perfusion; when perfusion of the laxative ceases, the secretion decreases and the return to the basal level is found an hour later. With DOSS and ricinoleic acid, the secretion is maximal at the outset and decreases between the 90th and 120th minute of perfusion; when perfusion of the laxative ceases, the secretion continues to decrease but is still raised an hour later.

There is a significant correlation between the water fluxes on the one hand and the sodium and potassium fluxes on the other for all the laxative tested $(P<0.001)$.

Table 1 Water secretion during basal period and under effect of laxatives and taurodeoxycholate (mean $\pm S E M)$

\begin{tabular}{|c|c|c|c|c|c|}
\hline & $\begin{array}{l}\text { Glycocholate } \\
(n=3)\end{array}$ & $\begin{array}{l}\text { Taurodeoxycholate } \\
(n=3)\end{array}$ & $\begin{array}{l}\mathrm{MgSO} \\
(n=4)\end{array}$ & $\begin{array}{l}\text { DOSS } \\
(n=3)\end{array}$ & $\begin{array}{l}\text { Ricinoleic acid } \\
(n=3)\end{array}$ \\
\hline $\begin{array}{l}\text { Basal period }(\mathrm{ml} / \mathrm{min} / 25 \mathrm{~cm}) \\
\text { Laxative perfusion }(\mathrm{ml} / \mathrm{min} / 25 \mathrm{~cm})\end{array}$ & $\begin{array}{l}-0.9 \pm 0.3 \\
-0.2 \pm 0.4\end{array}$ & $\begin{array}{l}+0 \cdot 3 \pm 0.3 \\
+4 \cdot 2 \pm 0 \cdot 5\end{array}$ & $\begin{array}{l}-0.1 \pm 0.2 \\
+0.8 \pm 0.1\end{array}$ & $\begin{array}{l}-0 \cdot 1 \pm 0 \cdot 2 \\
+5 \cdot 1 \pm 0.7\end{array}$ & $\begin{array}{l}-0 \cdot 9 \pm 0 \cdot 3 \\
+6 \cdot 2 \pm 2 \cdot 2\end{array}$ \\
\hline
\end{tabular}

The values indicated under perfusion of laxatives are average values obtained during the first 90 minutes for collection. 

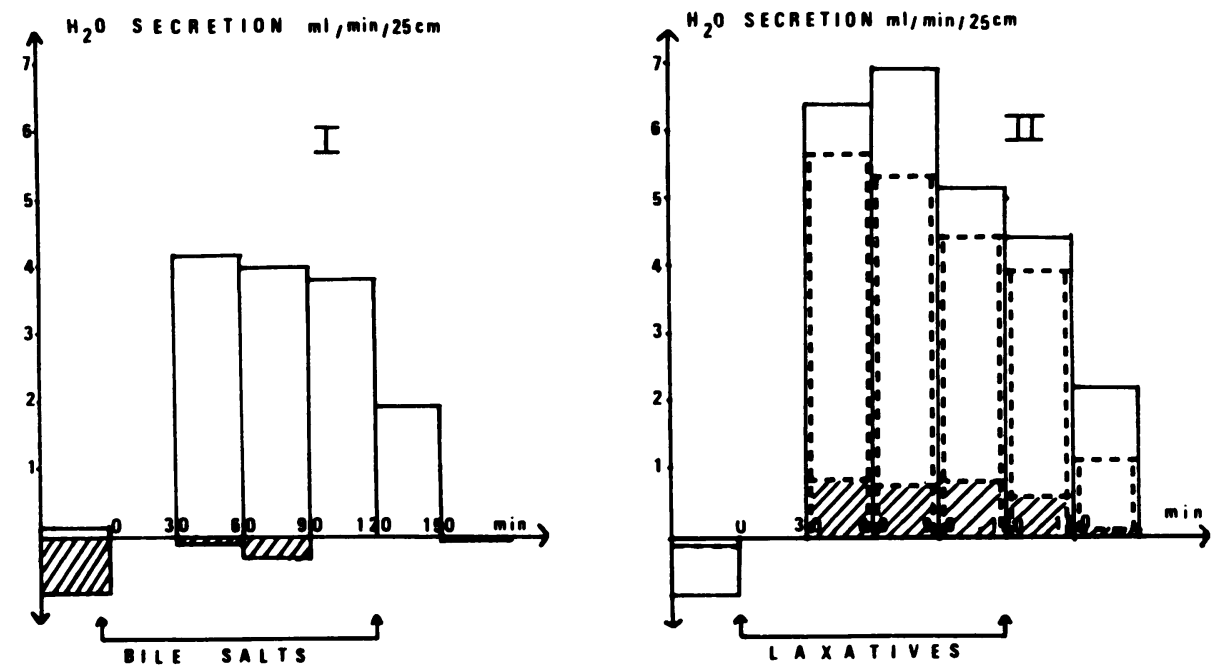

Fig. 1 Time course of water secretion during experiment. I bile salts: $\square T D C(n=3)$ IIIIZJ GC ( $n=3)$ II laxatives: $\square$ Ricinoleic acid $(n=3)[--] \operatorname{DOSS}(n=3)$ UIITD $\mathrm{MgSO}_{4}(n=4)$

Table 2 Increase in DNA losses and number of cells desquamated during laxative and taurodeoxycholate perfusions (mean $\pm S E M$ )

\begin{tabular}{llllcc}
\hline & $\begin{array}{l}\text { Glycocholate } \\
(n=3)\end{array}$ & $\begin{array}{l}\text { Taurodeoxycholate } \\
(n=3)\end{array}$ & $\begin{array}{l}M g S O \\
(n=4)\end{array}$ & $\begin{array}{l}\text { DOSS } \\
(n=3)\end{array}$ & $\begin{array}{l}\text { Ricinoleic acid } \\
(n=3)\end{array}$ \\
\hline $\begin{array}{l}\Delta \text { DNA }(\mu \mathrm{g} / \mathrm{min} / 25 \mathrm{~cm}) \\
\begin{array}{l}\text { Number of intestinal cells } \times 10^{\circ} \\
\text { desquamed } / 90 \mathrm{~min} / 25 \mathrm{~cm}\end{array}\end{array}$ & $\mathbf{8 . 3} \pm 3 \cdot 6$ & $\mathbf{5 5} \cdot 9 \pm 15 \cdot 3$ & $29 \cdot 1 \pm 11 \cdot 1$ & $824 \pm 92$ & $628 \pm 167$ \\
\hline
\end{tabular}

$\triangle$ DNA is the average value obtained during the first 90 minutes of collection.
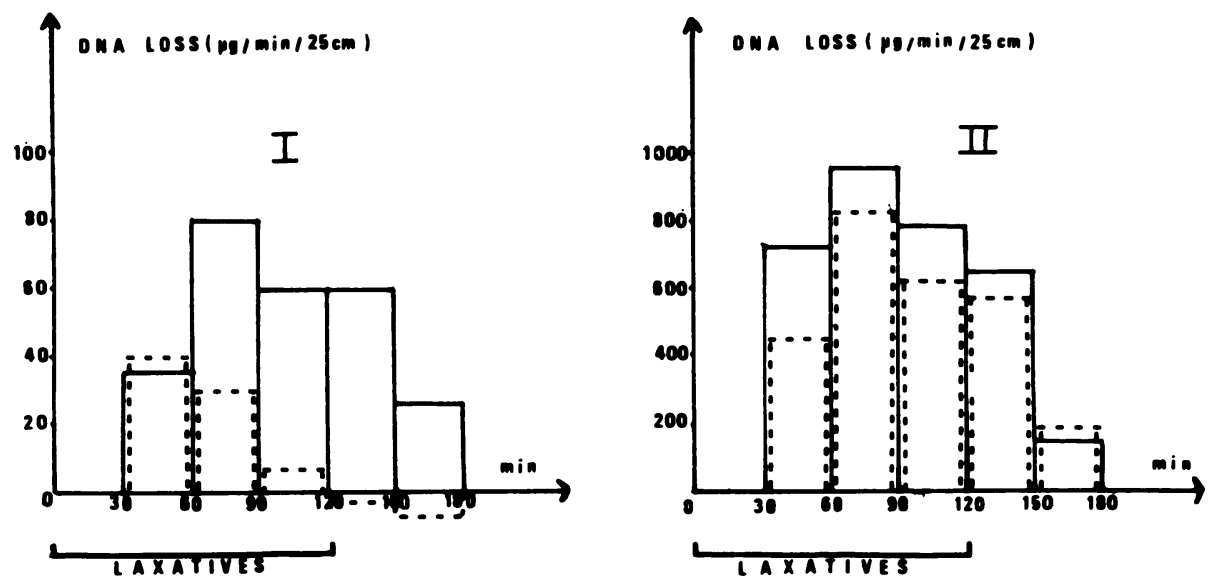

Fig. 2 Time course of DNA losses during experiment. $I \square T D C(n=3) \square=-J M g S L$. $(n=4)$ II $\square$ DOSS. $(n=3)[-\beth$ Ricinoleic acid $(n=3)$ 
Table 3 Enzyme activities (alkaline phosphatase, $\alpha$-glucosidase, leucyl $\beta$-naphtylamidase, and $N$ acetyl $\beta$-glucosaminidase) during and after TDC perfusion (multiplication coefficient in relation to its basal value)*

\begin{tabular}{|c|c|c|c|c|c|}
\hline & \multicolumn{5}{|c|}{ Perfusion (minutes) } \\
\hline & $30-60$ & $60-90$ & $90-120$ & $120-150$ & $150-180$ \\
\hline $\begin{array}{l}\text { Alkaline phosphatase } \\
\alpha \text {-Glucosidase } \\
\text { Leucyl } \\
\mathbf{N} \text { acetyl }\end{array}$ & $\begin{array}{r}5 \pm 1 \cdot 6 \\
4 \cdot 1 \pm 1 \cdot 1 \\
5 \cdot 4 \pm 1 \cdot 5 \\
5 \cdot 4 \pm 0 \cdot 8\end{array}$ & $\begin{array}{l}4 \cdot 1 \pm 1 \cdot 0 \\
3 \cdot 9 \pm 0 \cdot 8 \\
5 \cdot 0 \pm 1 \cdot 4 \\
5 \cdot 8 \pm 0 \cdot 9\end{array}$ & $\begin{array}{l}3 \cdot 4 \pm 1 \cdot 0 \\
3 \cdot 1 \pm 0 \cdot 7 \\
3 \cdot 8 \pm 0 \cdot 9 \\
4 \cdot 1 \pm 0 \cdot 3\end{array}$ & $\begin{array}{l}1 \cdot 8 \pm 0.3 \\
2 \cdot 5 \pm 0.6 \\
2 \cdot 5 \pm 0.5 \\
2 \cdot 8 \pm 0.5\end{array}$ & $\begin{array}{l}0 \cdot 7 \pm 0 \cdot 1 \\
1 \cdot 2 \pm 0 \cdot 5 \\
0.9 \pm 0 \cdot 3 \\
1 \cdot 1 \pm 0.4\end{array}$ \\
\hline
\end{tabular}

*Mean+SEM. $n=4$.

MANNITOL

The mean ratio $\frac{\text { mann A/mann } B}{\text { PEG A/PEG } B}$ for perfusion of the basal solution is $0.93 \pm 0.01$. Perfusion of laxatives or bile salts lowers this ratio by $-0.06(\sigma=0.08, \mathrm{P}<1 \%)$.

DNA LOSS

The amount of DNA collected during the basal period is $16.0 \pm 2 \cdot 2 \mu \mathrm{g} / \mathrm{mn} / 25 \mathrm{~cm}$. It increases under the effect of laxatives. An intestinal cell is known to contain $10 \mathrm{pg}$ DNA; it was therefore possible to calculate the number of cells which desquamated under basal conditions $\left(0.0016 \times 10^{9}\right.$ cells $\left./ \mathrm{mn} / 25 \mathrm{~cm}\right)$ and under the effect of the laxatives (Table 2).

The kinetics of DNA loss are shown in Fig. 2; with $\mathrm{MgSO}_{4}$ the loss is maximal at the outset and diminishes during perfusion of the laxative; with TDC, ricinoleic acid, and DOSS it continues throughout perfusion of the laxative and DNA loss is still significantly raised an hour later.

DNA loss and water fluxes: water and electrolyte secretion is maximal at the outset, while DNA loss is delayed. Nevertheless there is a significant correlation between these two when ricinoleic acid $(r=0.85)$ and DOSS $(r=0.90)$ are perfused.

\section{ENZYME ACTIVITY}

This was measured under the effect of TDC only and is expressed in Table 3 as a multiplication coefficient in relation to its basal value. Enzyme activity increased during perfusion. A study of the ratio enzyme activity

DNA loss enzymes preceding that of DNA.

\section{Discussion}

Our results confirm the secretory effect on the human jejunum of $\mathrm{MgSO}_{4}$, DOSS, ricinoleic acid, and TDC; but this secretory effect of $\mathrm{TDC}^{2}$, ricinoleic acid, ${ }^{7}$ and DOSS $^{6}$ is greater in our experiments, while the effect of $\mathrm{MgSO}_{4}$ is comparable. ${ }^{9}$ For TDC this discrepancy may be due to the difference in $\mathrm{pH}$ of the solutions tested, ${ }^{26}$ with the lower $\mathrm{pH}$ of our
TDC solution $(\mathrm{pH}=5)$ promoting increased fixation of bile acids on the cell brush border and increased secretion. $^{27}$

The water movements, being calculated with the variations of PEG concentration, are valuable only if PEG is not absorbable. An artefact might be introduced if PEG could diffuse through the mucosa made more permeable by the laxatives. This seems unlikely, for we added PEG C14 in the case of one of the patients tested with ricinoleic acid and found only $0.4 \%$ PEG C14 in the urine. This suggests that little or no PEG passed across the mucosa. Moreover, the effect of the change in permeability with respect to PEG and mannitol molecules is probably slight, as the ratio mann/PEG varies by only $-6 \%$ between the experiments without and with a laxative, while the radius of the mannitol and PEG molecules are very different.

For glycocholic acid our results also confirm that this trihydroxyl bile acid has no secretory effect. ${ }^{4}$

It may be asked whether anyone taking laxatives in the same dosage per os would secrete such large amounts of water. Saunders did, in fact, show in five ileostomised patients that phenolphthalein $(4 \times 100$ $\mathrm{mg} / 24 \mathrm{~h}$ ) increases the output of water from ileostomies by only $30 \%$ and of sodium by $39 \%{ }^{28}$ The large increased amounts (Table 1) secreted in our experiments may be due to the fact that the laxative is brought directly in contact with the jejunum.

Basal DNA loss rate in our experiments $(16 \mu \mathrm{g} /$ $\min / 25 \mathrm{~cm}$ ) appears to correlate well, after conversion to the same DNA units, with Croft's results $(28,75 \mu \mathrm{g} / \mathrm{min} / 25 \mathrm{~cm}){ }^{29}$ The number of cells lost in our experiments $\left(0.0016 \times 10^{9}\right.$ cells) appears also to correlate well with the results of McFarland (0.00145 $\times 10^{9}$ cells). ${ }^{30} \mathrm{By}$ applying to our experiments on $25 \mathrm{~cm}$ of jejunum the multiplying factor of 8 for the whole small intestine our results are also pretty close to those of Croft $\left(0.0128 \times 10^{9} / \mathrm{min}\right.$ and $0.02-0.05$ $\times 10^{9} / \mathrm{min}$ cells respectively). ${ }^{29}$ Our results confirm the aggressive effect of DOSS ${ }^{15}$ and ricinoleic acid ${ }^{15}$ that had already been observed in animal experiments. It is the first time, however, that this effect has been noted with a conjugated dihydroxyl bile acid. This result might be due to impurities in the TDC, which 
did in fact contain $2-4 \%$ free deoxycholate. But this concentration of free deoxycholate in the absence of additional intraluminal deconjugation is not sufficient to explain this effect, for it is known that in concentrations of $0 \cdot 2-0.4 \mathrm{mM}$ deoxycholate has no secretory effect.

For all that, it cannot be concluded that the bile salts play a physiological part in cell renewal, for, on the one hand, TDC was perfused in a concentration higher than its physiological jejunal concentration and, on the other hand, the secretory effect of dihydroxyl bile acid is known to be abolished by the addition of lecithins. ${ }^{4}$ Consequently, investigation of cell desquamation under more physiological conditions would be interesting.

Various explanations of the mechanism of cell desquamation may be put forward: Gullikson et al..$^{15}$ have shown the importance of the detergent power of laxatives: sodium dodecyl sulphate, dioctyl sodium sulphosuccinate, ricinoleate, deoxycholate caused exfoliation (DNA release), membrane effects (sucrase release), and shortened villi in hamsters. These biological effects were related to the surface properties of the agents. $\mathrm{Croft}^{31}$ has also shown that other irritants such as aspirin are responsible for the acute exfoliation effect (DNA release) on gastric mucosa.

The laxative might induce a certain amount of desquamation by its action on smooth intestinal muscle because villous spasmodic contraction causes a shedding of epithelium. ${ }^{32}$

It might be asked whether in our experiments the substantial rise in intraluminal water output had increased desquamation by an irrigating effect on the epithelium. This possibility can be excluded, for the work of L'Hirondel and Bernier ${ }^{30}$ has shown that cell loss is not influenced by intraluminal output (up to $20 \mathrm{ml} / \mathrm{mn}$ ), nor by perfusion time.

According to Lee, $^{29}$ cell desquamation is also dependent on intravillous pressure.

Two opposite hypotheses are conceivable: according to the first one, the secretion results from disturbances in epithelial permeability that are themselves dependent on cell changes caused by laxatives; according to the second, laxatives give rise to water and electrolyte secretion, which, by raising intravillous pressure, increases cell desquamation. In our experiments the fact that a linear relationship was found between water fluxes and DNA loss excludes neither of these two hypotheses.

The increase in intraluminal activity of the cell enzymes under the effect of TDC also accounts for the phenomenon of cell desquamation. The increase in the enzyme/DNA ratio in the very first collection may be the result of rapid disintegration of the cell membrane as much as actual enzyme secretion.

\section{References}

${ }^{1}$ Harries JT, Sladen GE. The effects of different bile salts on the absorption of fluid electrolytes and monosaccharides in the small intestine of the rat in vivo. Gut 1972; 13: 596-603.

${ }^{2}$ Russell RI, Allan JG, Gerskowitch VP, Cochran KM. The effect of conjugated and unconjugated bile acids on water and electrolyte absorption in the human jejunum. Clin Sci Mol Med 1973; 45: 301-11.

${ }^{3}$ Teem MV, Phillips SF. Perfusion of the hamster jejunum with conjugated and unconjugated bile acids: inhibition of water absorption and effects on morphology. Gastroenterology 1972; 62: 261-7.

${ }^{4}$ Wingate DL, Phillips SF, Hofmann AF. Effect of glycine conjugated bile acids with and without lecithin on water and glucose absorption in perfused human jejunum, J Clin Invest 1973; 52: 1230-6.

${ }^{5}$ Donowitz M, Binder HJ. Effect of dioctyl sodium sulfosuccinate on colonic fluid and electrolyte movement. Gastroenterology 1975; 69: 941-50.

${ }^{6}$ Saunders DR, Sillery J, Rachmilewitz D. Effect of dioctyl sodium sulfosuccinate on structure and function of human and rat intestine. Gastroenterology 1975; 69: 380-6.

${ }^{7}$ Ammon HV, Thomas PH, Phillips SF. Effect of oleic and ricinoleic acids on net jejunal water and electrolyte movement. J Clin Invest 1974; 53: 374-9.

${ }^{8}$ Malagelada Jr, Holtermuller KH, McGall JT, Go VLW. Pancreatic, gallbladder and intestinal responses to intraluminal magnesium salts in man. Am J Dig Dis 1978; 23 : 481-5.

${ }^{9}$ Wanitschke R, Ammon HV. Effects of magnesium sulphate on transit time and water transport in the human jejunum. Gastroenterology 1976; 70: 949 (abstract).

${ }^{10}$ Stewart JJ, Gaginella TS, Olsen WA. Inhibitory actions of laxatives on motility and water and electrolyte transport in the gastrointestinal tract. $J$ Pharmacol Exp Ther 1975; 192: 458-67.

${ }^{11}$ Guiraldes E, Lamabadusuriya SP, Dyesiku JEJ, Whitfield AE, Harries JT. A comparative study on the effects of different bile salts on mucosal ATP ase and transport in the rat jejunum in vivo. Biochim Biophys Acta 1975; 389: 495-505.

${ }^{12}$ Binder HJ, Filburn C, Volpe BT. Bile salt alteration of colonic electrolyte transport; role of cyclic adenosine monophosphate. Gastroenterology 1975; 68: 503-8.

${ }^{13}$ Coyne MJ, Bonorris G, Chung A, Conley D, Schoenfield LJ. Propanolol inhibits bile acid and fatty acid stimulation of cyclic AMP in human colon. Gastroenterology 1977; 73: 971-4.

${ }^{14}$ Cline WS, Lorenzsonn V, Benz L, Bass P, Olsen WA. The effect of sodium ricinoleate on small intestinal function and structure. J Clin Invest 1976; 58: 380-90.

${ }^{15}$ Gullikson GW, Cline WS, Lorenzsonn V, Benz L, Olsen WA, Buss P. Effects of anionic surfactants on hamster small intestinal membrane structure and function; relationship to surface activity. Gastroenterology 1977; 73: 501-11.

${ }^{16}$ Nell G, Forth W, Rummel W, Wanitschke R. Pathway of sodium moving from blood to intestinal lumen under 
the influence of oxyphenisation and deoxycholate. Naunyn Schmiedebergs Arch Pharmacol 1976; 293: 31-7.

${ }^{17}$ Fingl E. Laxatives and cathartics. In: Goodman LS, Gilman A, eds., Pharmacological basis of therapeutics. New York: Macmillan, 1970: 976-86.

${ }^{18}$ Modigliani R, Rambaud JC, Bernier JJ. The method of intraluminal perfusion of the human small intestine. I-Principe and technique. Digestion 1973; 9: 176-91.

${ }^{19} \mathrm{Hyden}$ S. A turbidimetric method for the determination of higher polyethylene glycol in biological materials K Lantbruksbrogsk Ann (Sweden) 1955; 22: 139-45.

${ }^{20}$ Corcoran AC, Page IN. A method for the determination of mannitol in plasma and urine. J Biol Chem 1947; 170: $165-71$.

${ }^{21}$ Le Pec JB, Paoletti C. A new fluorometric method for RNA and DNA determination. Anal Biochem 1966; 17: $100-7$.

${ }^{22}$ Peters TJ, Muller M, De Duve C. Lyososomes of the arterial wall: isolation and subcellular fractionation of cells from normal rabbit aorta. J Exp Med 1972; 136: 1117-36.

${ }^{23}$ Peters TS. Subcellular fractionation of the enterocyte with special reference to peptide hydrolases. In: Peptide transport in bacteria and mammalian gut. A Ciba Foundation Symposium. Amsterdam: Elsevier: 107-33.

${ }^{24}$ Iwata T, Yamasaki K. Enzymatic determination and thin layer chromatography of bile acids in blood. $J$ Biochem 1964; 56: 424-31.
${ }^{25}$ Rambaud JC, Thiry CH, Bernier JJ. Etude de l'absorption intestinale du sodium et du potassium par la perfusion intestinale de solutés isotoniques chez l'homme. Acta Gastroenterol Belg 1973; 36: 9-29.

${ }^{26}$ Ammon HV, Amarnani NH. Acid pH enhances the effect of taurodeoxycholate on water transport in the human jejunum (abstract). Gastroenterology 1978; 74: 1003.

${ }^{27}$ Wilson FA. Characterization of bile acid binding to rat intestinal brush border membranes. J Membr Biol 1977; 33: 213-30.

${ }^{28}$ Saunders DR, Sillery J, Surawica C et al. Effect of phenolphthalein on the function and structure of rodent and human intestine. Am J Dig Dis 1978; 23: 909-13.

${ }^{29}$ Croft DN, Loehry CA, Taylor JFN, Cole J. DNA and cell loss from normal small intestinal mucosa. Lancet 1968; 2: 70-3.

${ }^{30} \mathrm{McF}$ arland JB, Asplin A, Hallaway HM. A new method of studying intestinal mucosal dynamics. $B r J$ Surg 1968; 55: 786-9.

${ }^{31}$ Croft DN. Cell turnover and loss and the gastric mucosal barrier. Am J Dig Dis 1977; 22: 383-6.

${ }^{32}$ Lee JS. Epithelial cell extrusion during fluid transport in canine small intestine. Am J Physiol 1977; 232: E408-11.

${ }^{33}$ L'Hirondel C, Bernier JJ. Détermination par la technique de la perfusion intestinale, de la perte de cellules et de protéines dans le jéjunum humain normal. Gastroenterol Clin Biol 1979; 3: 147-52. 